DOI: 10.32370/IA_2021_09_16

\title{
Specificity of M. Novak's Activity in the Context of the Development of Ukrainian Film Production in the Countries of North America
}

\author{
Turchak Lesya Ivanovna \\ PhD in Art History, Associate Professor, \\ Kiev National University of Culture and Arts, \\ Kiev, Ukraine
}

The article examines the film production activities of one of the leading figures of socio-political and cultural life of the Ukrainian community in New York and Los Angeles in the mid-twentieth century. The activity of M. Novak in the context of the attempt to develop the Ukrainian film industry in order to outline the national identity is studied. The peculiarities of M. Novak's professional and public activity in the context of the specifics of the Ukrainian diaspora in Canada and the USA are revealed and his contribution to the Ukrainian film industry abroad is clarified.

The study found that the common semantic and stylistic basis of films of the Ukrainian diaspora in Canada and the United States in the 20-60's of the twentieth century. became the baggage of Ukrainian culture of their creators, the traditions of domestic cinema, in which they worked before emigrating, as well as the general attitude to the preservation of traditions of Ukrainian culture of the diaspora in North America, typical of the second wave of emigration in general.

Through his own activities in the field of film production and distribution of documentary and feature films, M. Novak contributed to the nation-building dialogue and the actualization of the communicative efficiency of world Ukrainians.

Keywords: M. Novak, Ukrainian film production, diaspora, USA, Canada, film producer, distribution, public activity.

Актуальність дослідження. Сучасні дослідники розглядають діаспору як невід'ємну складову нації, завданням якої є збереження української ідентичності, традицій, культури, мистецтва. Хвилі еміграції, які проходили в Україні сприяли тому, що велика кількість талановитих людей змушена була залишити батьківщину. Справу свого життя вони продовжили в еміграції, тим самим не лише зберегли культурні традиції а і продовжили їх, сприяли популяризації української культури в різних країнах Європи та Америки. Українське кіно в діаспорі розвивалось, видозмінювалось, набуваючи нових форм і наповнюючись новими сенсами відповідно до національної специфіки та культурної традиції країни. Феномен емігрантського кіно як і культури в цілому відтворює ситуацію вибуху та породженої ним культурної дисгармонії, що згодом упорядковується, набуваючи рис нової знакової системи (за Ю. Лотманом).

Кінематографічна, громадська та культурна діяльність М. Новака в українській діаспорі Канади та Сполучених Штатів Америки в контексті специфіки процесу 
культурної асиміляції, взаємоінтеграції та привнесеної традиції породжує феномен, що викликає науковий інтерес.

Аналіз публікацій. Дослідження протягом останніх тридцяти років стали популярним науковим напрямом у світовій гуманітаристиці, що розвивається в нову перспективну академічну дисципліну.

Незважаючи на науковий інтерес до різноманітних аспектів діяльності представників української діаспори, вітчизняними дослідниками професійна, громадська та культурна діяльність М. Новака лишається недостатньо невисвітленою. Однією з небагатьох наукових публікацій, присвячених постаті М. Новака в контексті кіновиробництва в Новому Світі є стаття Ю. Мицика «Спроба створення українського Голлівуду (Микола Новак)» [15]. Г. Карась в статті «Особливості менеджменту української музичної культури в діаспорі» [8] розглядає діяльність М. Новака як талановитого організатора театральних вистав, концертів, демонстрацій українських музичних фільмів. Окремі аспекти діяльності М. Новака висвітлено у наукових статтях, предметом дослідження яких став український закордонний кіноматограф першої половини XX ст. або творча діяльність відомих режисерів в еміграції, наприклад, публікації Л. Косаківської «Василь Авраменко - Іван Кавалерідзе: «кінодуель» через океан» [12], Р. Бучко та А. Дорошенка «Український закордонний кінематограф 19301945» [3], О. Ковальчук «Збереження та збагачення культурної спадщини українцями у США (кінець XIX - початок 40-х pp. XX ст.)» [10], I. Патрон «Кіноспадщина Юліана Дороша в контексті розвитку кіномистецтва на західноукраїнських землях у 20-30 роках ХХ століття» [18] та ін.

Мета статті - з'ясувати його внесок в українську кіноіндустрію за кордоном, виявити особливості професійної та громадської діяльності М. Новака в контексті специфіки української діаспори в Канаді та США.

Виклад основного матеріалу. Микола Новак народився 14 лютого 1902 р. у с. Мерешівка (Рогатинський повіт) у родині столяра, навчався в Рогатинській гімназії. В роки Першої світової війни юнак організував групу «Молода Січ», в яку входили тринадцять підлітків (прикладом для наслідування став український добровольчий легіон українських січових стрільців, що діяв у складі австро-угорської армії), в листопаді 1918 р., після проголошення Західноукраїнської народної республіки, вступив 
добровольцем до Української Галицької Армії, а після поразки в польсько-українській війні (1918-1919рр.), проводив активну пропагандистську діяльність серед українських вояків та вступив до лав Української військової організації (УВО), що сформувалася у 1920 р. Після демобілізації в 1926 р. М. Новак емігрував до Канади, поєднуючи громадсько-політичну діяльність (учасник Українського військового об'єднання) 3 роботою та захопленням театром (юнак брав участь у самодіяльному українському театрі) [9, с. 173].

У 1929 р. М. Новак переїхав до Сполучених Штатів Америки (м. Нью-Йорк), там продовжив громадсько-політичну діяльність, був одним із співорганізаторів Організації державного відродження України, перші осередки якої створені наприкінці 1920-х рр. під час перебування в Північній Америці голови Проводу українських націоналістів С. Коновальця. Головною метою організації, під час 1-го з’їзду в 1931 р., було затвердження фінансової підтримки та допомоги діяльності Українській військовій організації та Організації українських націоналістів, а згодом пріоритетним стало питання збереження національної ідентичності українців у Сполучених Штатах Америки [13, с. 235]. Діяльність М. Новака в межах організації як заступника ії голови зосереджувалася передусім на галузі театрального мистецтва. Зокрема, Г. Карась стверджує, що М. Новаком наприкінці 1920-х рр. - початку 1930-х рр. було організовано концерти танцюристів В. Авраменка, хорові концерти О. Кошиця, а також концертні виступи відомого соліста-баритона П. Ординського і скрипаля та композитора Р. Придаткевича [8, c. 178].

У 1931 р. М. Новак став менеджером однієї 3 шкіл українського танцю В. Авраменка та співорганізатором Ювілейного Комітету Українських Танцюристів, створеного до річниці діяльності українських танцюристів на території Північної Америки, що відбувся 25 квітня 1931 р. М. Новаку було доручено перевірити рівень майстерності хореграфів у найбільших осередках української діаспори та запросити їх для участі у святковій виставі в Метрополітен Опера. Внаслідок його організаційної діяльності в нью-йоркському концерті, метою якого було ознайомлення представників різних національностей з українським хореографічним мистецтвом, брали участь 500 танцюристів та 100 співаків, а зібрані кошти були передані В. Авраменко для подальшої популяризації української культури [17, с. 116-117]. 
Ю. Мицик наголошує, що саме тоді у М. Новака виник задум виробництва українських кінострічок [15, с. 43]. Натхненний результатами українського кіновиробництва в США та Канаді, ініційованого пастором Іваном Яцентієм (земляком М. Новака), зокрема німою кінострічкою «Галичина» (1929 р.), у 1934 р. М. Новак намагався запустити зйомки фільму про відомих серед української громади бойовиків ОУН, учасників однієї з найгучніших акцій націоналістичного підпілля на території міжвоєнної Польщі Василя Біласа та Дмитра Данилишина, розстріляних польською владою 23 грудня 1932 р. після чергового пограбування державного поштового відділення в містечку Городок біля Львова, проте через ряд об’єктивних причин реалізувати задум не вдалося. Р. Бучко наголошує, що зібраний М. Новаком матеріал став основою для написання п’єси, постановку якої йому вдалося здійснити лише в 1940х рр. після переїзду в м. Лос-Анджелес [3, с. 281].

Першим проектом М. Новака як кінопродуцента в Новому Світі стала кінострічка «Наталка Полтавка» (Наталка - співачка Метрополітен-Опери Т. Сабанієва, Петро - Д. Кріона, Микола - Ф. Свистун, Терпелиха - О. Діброва, Возний - М. Водяний та ін.). Дослідники стверджують, що 3 ініціативою екранізувати найвідомішу п’єсу I. Котляревського до М. Новака звернувся пропагандист української народної культури в цілому та українського танцю зокрема, відомий хореограф, засновник мережі танцювальних шкіл у містах Канади та США Василь Авраменко, у творчому доробку якого на той час було кілька німих фільмів [15, с. 43]. Як стверджує С. Мензелевський, В. Авраменко передусім прагнув «прославити українську культуру в Північній Америці поза локальним діаспорним контекстом» [14] та врятувати українську культуру від асиміляції. Його мета безсумнівно відповідала прагненням М. Новака на шляху до державного відродження України.

26 травня 1936 р. М. Новаком було організовано корпорацію першого звукового фільму «Наталка Полтавка» «Авраменко Філм Продакшн Інкорпорейтед», яку очолив М. Бойчук, а членами комітету були активні учасники Організації державного відродження України (М. Новак обіймав посаду секретаря), а за місяць до того започатковано спеціальний журнал «призначений українській фільмовій і балетній справі та народному житті» часопис «Промінь», основними призначеннями якого були заохочення потенційних інвесторів, популяризація майбутньої стрічки серед української громади 
Північної Америки та чітке формулювання головного «меседжу» фільму. Редактор часопису $€$. Скоцко наголошував на тому, що значення кінострічки передусім було культурно-політичним, оскільки представлені українській громаді в США та Канаді українські радянські фільми - це позбавлена національного духу «російськобольшевицька пропаганда» [19, p. 701]. Проте, дослідники наголошують на відсутності бажання у представників антибільшовицьких митців співпрацювати, наприклад, С. Мензелевський стверджує, що О. Кошиць, відомий український диригент i композитор, відмовився працювати над фільмом В. Авраменка, тому вирішено було запросити К. Швєдова, викладача Московської консерваторії. У доповіді «Як повстала українська фільма «Наталка Полтавка» М. Новак також акцентує на конфлікті О. Кошиця 3 хореографом, його негативній рецензії, надруковані у газеті «Свобода», а також на тому, що режисером стрічки став американський режисер Е. Улмер, «бувший асистент славного на ввесь світ театрального режисера Рейнгардта» [4]. Варто зазначити, що М. Новак також був задіяний у кінознімальному процесі як актор (Landlord). В одному 3 інтерв'ю Е. Улмер стверджує, що кошти на кіновиробництво (понад 18000 доларів) були зібрані членами Спілки мийщиків вікон в Нью-Йорку, які заздалегідь продавали білети на кіносеанси, а на знімальний майданчик приїздили діти зі своїми костюмами з усієї країни для виконання танцювальних номерів [19, p. 701].

Прем'єрний показ кінофільму українською мовою (з субтитрами англійською) відбувся в нью-йоркському кінотеатрі «Венеція» (7-ма авеню) 25 грудня 1936 р. Незважаючи на неабиякий інтерес серед глядачів Сполучених Штатів Америки (кінострічку було показано в найбільших осередках української діаспори - Буфало, Бостон, Чікаго, Філадельфія, Детройт та ін.) і Канади (з березня 1937 р. фільм показано в Клівленді, Едмонтоні, Торонто, Саскауні, Вінніпезі), а також в цілому досить схвальні рецензії на кінострічку в періодичних виданнях (лише окремі сцени та танцювальні номери були розкритиковані режисером $Є$. Деславом та О. Кошицем), фільм провалився у прокаті через невдалу дистриб'юторську стратегію та замалі інвестиції в рекламу. $3 \mathrm{i}$ спогадів М. Новака дізнаємося, про особливості дистрибуції кінострічки в містах Канади: «Крім летючок різних, афішів, оголошень в пресі, найняли ми фармера з білими кониками, збудували на його санях «українську хату», а на хату начепляли різні великі реклами, попросили дві дівчини, які через мікрофони голосили кожного дня по полудні 
про прем’єру фільму «Наталка Полтавка» [7, с. 232]. На заваді популяризації української кінострічки в Новому Світі стала і зовнішня політика Радянського союзу. 3 метою нівелювання «націоналістичного» впливу серед української громади в США радянською владою було ініційовано екранізацію опери М. Лисенка «Наталка Полтавка» на кіностудії «Українфільм» (режисер І. Кавалерідзе, Наталка - К. Осмяловська, Микола С. Шкурат, Петро - М. Платонов) та прем’єрного показу першої кіноопери українського кіномистецтва практично одночасно з версією кінокорпорації М. Новака в США (на початку лютого 1937 р. корпорацією «Амкіно» фільм було випущено в прокат в кінотеатрі «Рузвельт») [7, с. 165]. На думку М. Новака, яку він висловив на нараді членів корпорації, дистрибуція радянської версії «Наталки Полтавки» - саботаж Москви, задуманий з метою «вбити наш бізнес» [17, с. 153]. Як наслідок внутрішніх розбіжностей між членами студії «Авраменко фільм» корпорація розділилася на дві групи: перша, очолена В. Авраменком, утворила корпорацію «Укрфільм» та розпочала зйомки фільму «Запорожець за Дунаєм», а друга - фільму «Маруся» за твором М. Старицького (невдовзі після прем’єри В. Авраменко викупив права на показ кінострічки на території Північної Америки) [3, с. 280].

М. Новак у складі другої групи розпочав роботу над екранізацією п’єси «Ой не ходи, Грицю, на вечорниці» на кошти української громади, залучивши до співпраці виключно провідних українських діячів культури і мистецтва діаспори США та Канади: Л. Булгакова (режисер), О. Кошиця (композитор, керівник хорової музики, диригент хору та фахівець з етнографіï), Р. Придаткевича (композитор оркестрового супроводу та диригент оркестру), А. Кистя та В. Кедровського (автори сценарію), Г. Кириченка (диригент); акторів: С. Мельник - Маруся, М. Стегницького - Микола, П. Чорнюка Хома, М. Скоробогача - Дмитро, Н. Троїцьку - Галина, С. Доню - Дарина, Г. Троян Оксана, а також активістів $з$ діаспори. М. Новак зіграв епізодичну роль Потапа, батька Марійки. Кінострічка «Маруся», на думку дослідників, «значно перевищила «Наталку» 3 мистецького боку» [15, с. 44], а завдяки більш вдалій дистриб'юторській стратегії мала неабиякий успіх у прокаті, проте без сумніву конкурувати з художніми фільмами американського виробництва не могла.

Дослідники кінематографу наголошують, що рівень конкурентоздатності конкретної кінематографії залежить від трьох груп факторів: стан, постановка та 
ідеологія кіносправи; тип та особливості зовнішнього соціального контексту; характер взаємодії кінематографу з зовнішнім громадським середовищем [5, с. 98]. Розуміючи, що з багатьох об’єктивних і суб'єктивних причин, у тому числі обмеженість глядацької аудиторії за етнічним показником, недостатне фінансування (художні фільми «Наталка Полтавка» та «Маруся» були зняті власним коштом українських емігрантів), втручання з боку радянської влади та ін., М. Новак сфокусувався на створенні документальних фільмів.

Завдяки організаційним здібностям М. Новака спілкою В. Авраменка було озвучено фільм «Галичина», «Гуцульщина», завершено зйомки документального фільму «Трагедія Карпатської України» режисера К. Лисюка, присвяченого темі боротьби українців Закарпаття за незалежність (кошти з показу фільму в містах США та Канади були призначені на зйомки короткометражних кінострічок з життя української еміграції та завершення фільму «Тріумф українського танцю» В. Авраменка) [2, с. 6], а також «вдалий документальний кінорепортаж» [9, с. 173] про Перший Конгрес Українців Америки (липень 1940 р.). Кінострічка «Галичина» І. Яцентія, відзнята в 1934 р. частково в Рогатинщині, була призначена для ознайомлення глядачів США з пам'ятними місцями української землі (Княжа гора, церква Святого Юра, Театр Стадника, Волоська Церква та ін.) та розкриття етапів визвольної боротьби українського народу. Німий фільм було перемонтовано та озвучено за методом кінотехніка С. Федіва, що полягав у магнетичному озвучуванні. Дослідники наголошують, що ця стрічка, разом із фільмом «Мистецький документ з гуцульського весілля», знятого І. Яцентією в 1936 р. «викуплені Миколою Новаком, який у 1950-х роках активно демонстрував ці кінотвори в українських осередках у США та Канади» [3, с. 255]. Б. Берест, відомий історик діаспори, до переліку німих кінофільмів, які були озвучені С. Федівим для фірми М. Новака додає фільм «Гуцульщина», відзнятий Ю. Дорошем в 1938 р. [1, с. 195].

На думку В. Ковпак, кінематографічна діяльність українців в еміграції стала потужним соціокомунікативним каналом інформаційного простору, унікальним «концентрованим багатоступеневим кодом репрезентації різних інформаційних моделей медіакартини світу» [11, с. 23].

У 1941 р. М. Новак здійснив дистрибуцію «фільмової драми із життя закарпатських українців» «Забутий край» (перша назва «Марійка Невірниця», режисер 
В. Ванчура, автор сценарію І. Ольбрахт, К. Нови), прем’єра якої в Сполучених Штатах Америки відбулася в Нью-Йорку 1 листопада 1941 р. Варто зазначити, що фільм було знято в 1934 р. на Закарпатті в селах біля Чорної Ріки чеською фільмовою компанією «Славія фільм», головну роль виконав А. Кість, а решту - місцеві жителі, включно 3 виконавицею головної жіночої ролі Г. Шкелебей [16, с. 4]. Силами спілки кінострічку субтитровано англійською мовою [3, с. 281].

У 1943 р. М. Новак переїздить до Лос-Анджелесу, ставши співзасновником місцевого українського культурного осередку, працював над написанням кіносценаріїв («Ілюзії Москви») та статей на тему кіномистецтва і життя в Голлівуді до журналів і часописів [9, с. 173].

Активний «організатор українського життя в Лос-Анджелесі» [6, с. 8] М. Новак пропагував національну культуру за кордоном. Зокрема був одним із засновників та президентом Українського культурного центру (Лос-Анджелес, Каліфорнія; перша назва Український соціальний центр), заснований в 1944 р. для пропаганди соціального та культурного життя українців та надання взаємодопомоги, а також членом Ради мерії 3 міжнародних візитів. Ним було організовано численні концертні виступи капели бандуристів Г. Китастого, ансамблю «Калина», хорів під керівництвом Р. Кичмарського, В. Чайковського, сольних виступів інструменталістів та багатьох зірок української опери [17, с. 494-498]. У 1956 р. М. Новаком засновано український театр «Київ» (ЛосАнджелес), в якому 27 жовтня того ж року проведено концерт провідних солістівінструменталістів та оперних співаків з Сан-Франциско: І. Вовка, А. де Пом'ян, О. Задорожної-Акіншиної, В. Мартиненка, В. Чайковського та ін.

У 1979 р. надруковано спогади М. Новака «На сторожі України», присвячені українській еміграційній кінопродукції [17].

Висновки. Діяльність М. Новака в галузі кіноіндустрії отримала виявлення в контексті організації кінознімального процесу, надзвичайно активної продюсерської діяльності, дистрибуції українських кінострічок та пропагуванні української культури в країнах Північної Америки.

Дослідження виявило, що спільною основою виробництва художніх та документальних кінострічок, розвитку яких сприяв М. Новак, стали надбання української культури їх творців, традиції вітчизняного кіно, в якому вони працювали до 
від’їзду в еміграцію, а також загальна установка назбереження традицій української культури діаспори в Північній Америці, характерна для другої хвилі еміграції в цілому.

Власною діяльністю в галузі кіновиробництва та дистрибуції документальної і художньої кінопродукції, М. Новак посприяв забезпеченню націотворчого діалогу та актуалізації комунікативної ефективності світового українства.

\section{References}

1. Berest, B. (1964). History of Ukrainian cinema. New York.

2. Buchko, R. (1991). We know ours abroad. Movie screen news, no. 7, p. 6.

3. Buchko, R., Doroshenko, A. (2016). Ukrainian foreign cinema 1930-1945. History of Ukrainian cinema 6 in 5 volumes Vol. 2: 1930-1945.

4. Reviews about the first Ukrainian sound film "Natalka Poltavka". December 1936 TsDAVO of Ukraine. F. 4465. Op. 1. Ref. 1022. Arc. 4.

5. Zhabskiy, M. I. (2011). Factors of competitiveness of national cinematographies. VGIK Bulletin, no. 10, pp. 96-110.

6. Seidler, N. "Will you forgive me, my mother-in-law...": life and creative paths in the homeland and abroad of Ukrainian Ivan Ovechko. URL:

http://library.mlt.gov.ua/images/kraieznavstvo_Melitopolia/Natalia_Zaidler.pdf

7. Kavaleridze, I. P. (2017). Memoirs. Drama. Journalism / compiler S. Menzelevsky. Kyiv: Oleksandr Dovzhenko National Center.

8. Karas, G. V. (2016). Features of management of Ukrainian musical culture in the diaspora. Carpathian region, no. 1 (8), pp. 177-184.

9. Book of artists and figures of Ukrainian culture (1954). The first meeting of Ukrainian artists from Canada and America with citizenship. Toronto.

10. Kovalchuk, O. (2005). Preservation and enrichment of cultural heritage by Ukrainians in the United States (late nineteenth - early 40's of the twentieth century.). Ukraine of the XX century: Culture, ideology, politics, Issue 9, pp. 753-773.

11. Kovpak, V. A. (2017). Information and communication activities of postwar Ukrainian emigration: the semantic matrix of the idea of the nation. Abstract of Ph.D. Zaporozhye : Classical Private University.

12. Kosakivska, L. (2003). Vasyl Avramenko - Ivan Kavaleridze: "film duel" across the ocean. Cinema Theater, no. 4, pp. 8-10.

13. Kucheruk, O. S. (2010). Organization of State Revival of Ukraine (ODVU). Encyclopedia of the History of Ukraine: Vol. 7. Kyiv: Naukova Dumka.

14. Menzelevsky, S. (2017). In the struggle for the "national film", or How Ukrainians made films in America. Ukrainian Pravda. May 23, 2017. URL : https://life.pravda.com.ua/culture/2017/05/23/224323/. 
15. Mytsyk, Y. (2020). Attempt to create Ukrainian Hollywood (Mykola Novak). Cinema, no. 2, pp. 43-44.

16. Novak, M. (1941). The forgotten land. Freedom. October 24, 1941. Part 246. P. 4.

17. Novak, M. (1979). On guard of Ukraine: own memories, historical materials, documents, correspondence, archive. Los Angeles, California: Published by the author.

18. Patron, I. (2018). Film heritage of Julian Dorosh in the context of the development of cinema in Western Ukraine in the 20-30s of the twentieth century. Scientific Bulletin of the IK Karpenko-Kary Kyiv National University of Theater, Film and Television, Issue 23, pp. 92100.

19. Gevinson, A. (Ed.). (1997). The 1911-1960: American Film Institute Catalog of Motion Pictures Produced in the United States: Within Our Gates: Ethnicity in American Feature Films / American Film Institute. University of California Press.

\section{Translation of the References to the Author's Language}

\section{Список використаних джерел}

1. Берест Б. Історія українського кіно. Нью-Йорк, 1964. 272 с.

2. Бучко Р. Знаймо наших за кордоном. Новини кіноекрану. 1991. № 7. С. 6

3. Бучко Р., Дорошенко А. Український закордонний кінематограф 1930-1945. Історія українського кіно 6 у 5-ти т. Т. 2 : 1930-1945 / голов. ред. Г. Скрипник; НАН України ; ІМФЕ ім. М .Т. Рильського. Київ, 2016. 448 с.

4. Відгуки про перший український звуковий фільм «Наталка Полтавка». Грудень 1936 р. ЦДАВО України. Ф. 4465. Оп. 1. Спр. 1022. Арк. 4.

5. Жабский М. И. Факторы конкурентоспособности национальных кинематографий. Вестник ВГИК. 2011. № 10. С. 96-110.

6. Зайдлер Н. «Чи простиш, моя ненько-вкраїно...»: життєві і творчі дороги на батьківщині та за їі межами українця Івана Овечка. URL : http://library.mlt.gov.ua/images/kraieznavstvo_Melitopolia/Natalia_Zaidler.pdf звернення : 12 червня 2021).

7. Кавалерідзе I. П. Мемуари. Драматургія. Публіцистика / упорядник С. Мензелевський. Київ : Національний Центр Олександра Довженка, 2017. 688 с.

8. Карась Г. В. Особливості менеджменту української музичної культури в діаспорі. Карпатський край. 2016. № 1 (8). С. 177-184.

9. Книга мистців і діячів української культури. Перша зустріч українських мистців Канади й Америки з громадянством. Торонто 1954. 316 с.

10. Ковальчук О. Збереження та збагачення культурної спадщини українцями у США (кінець XIX - початок 40-х рp. XX ст.). Україна XX ст.: Культура, ідеологія, політика. 2005. Вип. 9. С. 753-773. 
11. Ковпак В. А. Інформаційно-комунікаційна діяльність післявоєнної української еміграції: смислова матриця ідеї нації : автореферат дис. доктора наук із соціальних комунікацій : 27.00.01 / Класичний приватний університет. Запоріжжя, 2017. 40 с.

12. Косаківська Л. Василь Авраменко - Іван Кавалерідзе: «кінодуель» через океан. Кіно Театр. 2003. № 4. С. 8-10.

13. Кучерук О. С. Організація державного відродження України (ОДВУ). Енциклопедія історії України: Т. 7: Мі-О / редкол.: В. А. Смолій (голова) та ін. НАН України. Інститут історії України. Київ : Наукова думка, 2010. 728 с.

14. Мензелевский С. У боротьбі за «національну фільму», або Як українці знімали кіноопери в Америці. Українська правда. 23 травня 2017. URL: https://life.pravda.com.ua/culture/2017/05/23/224323/ (дата звернення : 12 червня 2021).

15. Мицик Ю. Спроба створення українського Голлівуду (Микола Новак). КіноТеатр. 2020. № 2. С. 43-44.

16. Новак М. Забутий край. Свобода. 24 жовтня 1941. Ч. 246. С. 4.

17. Новак М. На сторожі України: власні спогади, історичні матеріали, документи, листування, архів. Лос Анджелос; Каліфорнія: Накладом автора, 1979. 604 с.

18. Патрон I. Кіноспадщина Юліана Дороша в контексті розвитку кіномистецтва на західноукраїнських землях у 20-30 роках XX століття. Науковий вісник Київського національного університету театру, кіно і телебачення імені І. К. Карпенка-Карого. 2018. Вип. 23. С.92-100.

19. Gevinson A. (Ed.). The 1911-1960: American Film Institute Catalog of Motion Pictures Produced in the United States: Within Our Gates: Ethnicity in American Feature Films / American Film Institute. University of California Press, 1997. 1344 p. 